RAPHISA.

Revista de Antropología y Filosofía de lo Sagrado Review of Anthropology and Philosophy of the Sacrum

ISSN: 2530-1233 $\mathrm{N}^{\circ}$ 2, diciembre (2017) pp.: 67-79

\title{
SACRED PLACES IN BUDDHISM OR THE PLACE OF THE SACRED IN BUDDHISM
}

\section{LOS LUGARES SAGRADOS EN EL BUDISMO O EL LUGAR DE LO SAGRADO EN EL BUDISMO}

\author{
Antoaneta Nikolova ${ }^{1}$ \\ The South-West University (Blagoevgrad, Bulgaria)
}

\begin{abstract}
The paper aims to examine the meaning of sacredness in such a religion as Buddhism where there is no idea of God or any supernatural being. Instead, there are elaborated inner practices for achieving enlightenment. The paper consists of two parts. The first one analyses the place of the sacred in Buddhism considering the two important concepts of samsara and nirvana. The second part discusses sacred places in Buddhism comparing two different space structures: stupa as representative for a vertical structure and mandala for a horizontal one. On the base of juxtaposing these seemingly opposite concepts and structures the paper reveals that in terms of Buddhism the real sacredness is non-sacredness: a term that transcends the opposition sacred-profane and expresses the specific Buddhist vision of non-duality.
\end{abstract}

Key words: Buddhism; sacred-profane; non-duality.

Resumen: Este artículo tiene el propósito de examinar el significado de lo sagrado en una religión como el Budismo, donde no hay una idea de Dios como tal o ningún ser sobrenatural. En cambio, hay prácticas íntimas elaboradas para lograr la iluminación. El artículo tiene dos partes. La primera analíza los lugares sagrados en el Budismo, considerando así dos conceptos importantes el samsara y el nirvana. En la segunda parte se trata de los lugares sagrados en el Budismo comparando dos estructuras espaciales: la estupa como representativa de una estructura vertical y el manadala como horizontal. Tomando como fundamento la yuxtaposición de estos, aparentemente, conceptos y estructuras opuestas, el artículo revela que en términos del Budismo lo verdaderamente sagrado es lo no-sagrado: este es un término que trasciende la oposición sagrado-profano y expresa la visión específica budista de la no-dualidad.

[1] (tonishan1@yahoo.com ) Antoaneta Nikolova graduated in philosophy from the Sofia University «St. Kliment Ohridski» in 1987. She received her Ph.D. degree in philosophy from the Bulgarian Academy of Sciences in 1995. Since 2006 she is Associate Professor in History of philosophy at South-West University, Blagoevgrad, Bulgaria. Her main research interests are in the fields of Eastern philosophy, comparative philosophy, comparative religions, and philosophical problems of ecology. Currently she is a Marie Sklodowska-Curie fellow at the Leipzig University

This research is funded by the European Union's Horizon 2020 Research and Innovation Program through the Marie Sklodowska-Curie Action, grant No 753561. 
Palabras claves: Budismo; sagrado-profano; no-dualidad.

\section{Introduction}

Buddhism is a strange religion, a «religion of no-religion» as Alan Watts called it ${ }^{2}$. In Buddhism there is neither an Almighty God, God Creator, omniscient, omnipresent and omnipotent that should be obeyed and feared, nor any higher supernatural power controlling our destinies, nor any divine revelations or divine messengers. In such a case, how can there be a sense of sacrality? In what sense can we call the symbols of Buddhist religion sacred? What is the meaning and aim of sacred places in Buddhism? Is there any space for the sacred within Buddhist teaching? These are the questions that this paper aims to answer.

\section{The place of the sacred in Buddhism}

In Buddhism, there certainly are two terms that correspond to the opposition sacred-profane. These are nirvana and samsara. Samsara is the aspect of movement and restlessness, nirvana - the aspect of peace and serenity.

According to the Indian thought samsara is a beginningless cycle of reincarnations, where all living beings are captured «like a miserable prisoner rattled around overcrowded jails» ${ }^{3}$. Existing in this cycle means constant reiteration of the same situations and roles, painful monotony and transition from one form of suffering to another without idea of developing or ascending to the Absolute because «the idea of evolution is completely alien to the religions of India $\prime^{4}$. Therefore, it is conceived as a state of unfreedom and painful enslavement. The doctrine of samsara has a pre-Buddhist origin «but it was Buddhism that elaborated it in details, clearly articulated and made it the basic part of its teaching» ${ }^{5}$. Buddhism defines three characteristics of samsara that apparently belong to the profane: anatman (non-self or substanceless), dukkha (suffering) and anitya (impermanence of all being). Sometimes samsara even receives a fourth characteristic - impurity.

[2] Watts, A.: Buddhism: The Religion of Non-Religion. Boston: Tuttle Publishing, 1999.

[3] Ermakova, T., E. Ostrovskaya: Classical Buddhism. SPb: «Azbuka-classica», «Peterburgskoe Vostokovedenie», 2004. p. 42.

[4] Torchinov, E: Introduction into Buddhism. SPb: The Philosophical Society of Sankt-Petersburg, 2000 p. 23.

[5] Ídem 
If we examine the structure of samsara however we will find that the belonging of some of its components to the profane is strange. Exactly this, however, reveals the specifics of the Buddhists attitude to the sacred. According to the vertical spatial Buddhist cosmology, samsara has three main levels: Formless realm, Form realm and Desire realm. The Desire realm is the lowest level. Its inhabitants are striving for objects that can bring a sensual delight. In its turn the Desire realm consists of six spheres, the highest of which belonging to beings informally classified as "deities» (devas). Above the world of desire and senses there are located the two others realms. Higher kinds of devas dwell there together with advanced meditators and yogis. In these levels, there is no attraction to the sensual objects and therefore there is no 'suffering as such" or "suffering of change» ${ }^{6}$. Beings there enjoy pleasure and contentment, their life is extremely long. Exactly this, however, makes them not free from desire, "they are passionately attached to the very process of existence» ${ }^{7}$. Therefore, all these deities are also considered to be ultimately dependent beings "suffering in the ongoing cycle of death and subsequent rebirth" ${ }^{8}$ like all others. The only difference is that they live «a longer-lived and generally more blissful state than humans» ${ }^{9}$. Therefore, «even though Buddhists refer to devas as 'gods', they are not deities in the sense that we would use the term in the West ${ }^{10}$ and cannot be object of cult or devotion.

Buddhism perceives the realms themselves in a very specific way. According to its teaching, they do not have any determined space localisation. Buddhism does not regard them in their physical or spiritual existence. They are but a manifestation of the state of consciousness of the beings inhabiting them. Every kind of being unfolds its own reality. Therefore the Cosmos is not some strict and established reality with its physical or spiritual dimensions, but a psycho-cosmos - «a world experienced by living beings, a world as an aspect of their psychic experience» ${ }^{11}$. So, the different realms are different levels of unfolding the consciousness of living beings. In this way, each realm corresponds to a particular mental state or a state of being. It does not have its own temporal or spatial location and existence. «It is the beings that compose it. The physical separation is not

[6] Ermakova, Ostrovskaya: op. cit., p. 43

[7] Ídem

[8] Laynton, R.: Behind the Mask of God. UK: Stoke-on-Trend: Companion Guides 2013, p. 40.

[9] Ídem

[10] Ibídem, p. 41

[11] Torchinov, E.: World Religions. SPb: Centre «Peterburgskoe Vostokovedenie». 1998, p. 224 
so important as the difference in the mental state; humans and animals, though they partially share the same physical environments, still belong to different worlds because their minds perceive and react to those environments differently» ${ }^{12}$. A very important aspect of the same vision is that "for the Buddhist thinker there are not separated "man» and "sun» but some united field of experience - «a man seeing the sun» ${ }^{13}$. In such a way there are no more outer objects but objects perceived by human beings and becoming a part of his/her inner world, "this is not a world we live in but a world we experience» ${ }^{14}$. In such a way subject and object, Cosmos and psyche, inner and outer world coincide and lead to each other. Therefore the state of mind or consciousness is of great importance.

Except only some forms of Yogachara, however, Buddhism does not deny the existence of Ultimate Reality. The vision of this Reality, called also Void or Tathata (Suchness), is an essence of Awakening. Therefore, Buddhists seek to go beyond all forms of sansaric unfolding of consciousness, even those that belong to the most blissful or advanced beings in the realms of Form and Formless. Buddhists have the same attitude to the being of the highest spheres as to the beings of the lowest levels of the vertical structure. According to Buddhism, all beings are equal and although the quality of life in different levels is different, eventually the power of karma that determines this quality of life is exhausted and a new life in a new level begins. There is only one kind of reincarnation that is better than the others: it is the reincarnation as a human being. For the Buddhists, the existence in the form of a human being is the most precious one. Buddhism honours this state because according to its teaching it is only from that level that Enlightenment can be achieved.

The state that is beyond all states, forms, levels and realms of samsara is nirvana. Early Buddhism said that nirvana cannot be explained and does not belong to the dimensions of space and time. Therefore, it is close to the idea of sacrality.

Nirvana can be conceived as an opposite and an end of the samsara being. While samsara is perpetual unrest and unfolding of the consciousness, in nirvana the excitement of the world subsides, it literally implies extinction of the restlessness, or abatement of the movement. Nirvana means the definitive cessation of the unrest, radical transformation of consciousness, upturn in its very basis, its transformation into non-consciousness. Nirvana is not nothingness, «neither God nor impersonal Ab-

[12] Ídem

[13] Torchinov, E: Introduction into Buddhism. p. 32.

[14] Ídem 
solute ${ }^{15}$, but a state of freedom from all desires, attachments and suffering, a state of the highest bliss. It does not mean annihilation of being, «it however is not non-being, as well as it is not being, the disappearance of the notions of being and non-being is called nirvana ${ }^{16}$.

Beings that are connected to nirvana are the beings that deserve special attitude in Buddhism. It however is a religion with many faces. Buddhism varies greatly in countries and centuries, developing many forms, schools, sects and branches. Its three dominant strains: Theravada, Mahayana, and Vajrayana, have their unique approaches to the Buddha teaching, practice, and even to the final aim of this practice. In each of these trends there are even somewhat different attitudes to Buddha and different devotional figures.

Theravada, "Doctrine of the Elders,» is the most ancient form of Buddhism. It emphasises on rigid monastic practices: strict studying of ancient texts, meditation, and following the eightfold path. It accepts Buddha as historical person and sees its ideal in the arhat, "a fully perfected renunciatory saint who achieved nirvana by practicing the path set forth by Gautama in the sutras and in the vinaya regulations» ${ }^{17}$. The arhat attains nirvana for himself and will have no more incarnation in any of the realms of Buddhist Universe.

For Mahayana Buddhists this selfish end is not Enlightenment. They proclaim the idea that every living being has a potential Buddha nature and sees its ideal in Bodhisattvas (Enlightened beings) who work, with their wisdom and compassion, to liberate other sentient beings from the suffering. Mahayana also recognises «the immediate importance and relevance of many other Buddhas» ${ }^{18}$.

Vajrayana encourages rituals, chanting, and tantra techniques as well as honouring the root lama and Buddha aspects (Yidams).

Do Buddha, Arhats, Bodhisattvas, and Yidams replace the missing god and deities in Buddhist religion? All of them certainly became devotional figures but the specific of Buddhism is that they are mostly examples of the goal, aspects of one's own mind on the path to the goal or supporters in the process of Buddhist practice.

[15] Ibídem, p. 27.

[16] Nagarjuna: Ratnavali (Precious Garland), in: Frauwallner, E. Anthology of Buddhist Philosophy. Sofia: Evrasia. 1995, p. 162.

[17] Reynolds, F. and Jason A. Carbine eds. The Life of Buddhism. Berkeley and Los Angeles, California: University of California Press. 2000, p. 8.

[18] Ídem 
Practice is the most important thing in Buddhism. Its importance means that Buddhism is not a religion of faith and devotion. It does not matter whether one believes in Buddha or not. In order to achieve his/her goal he/she should rely only on himself/herself and his/her efforts. The very authority of Buddha insists: "Do not accept anything because it is said by a Buddha. Be a cresset for yourself.» Bodhisattvas and Yidams can support the adept but everybody has to pass the path by themselves. At the same time according to Mahayana Buddhism nobody can be liberated alone; moreover, the achievement of one being influences the state of all others. Even the state of the Universe in one of its temporal unfoldings influences and determines its future states. Therefore, each human being is greatly responsible for his/her own precious human existence as well as for the existence of all other beings.

So, in Buddhism there is no honouring or worshiping of deities and supernatural powers but rather relaying on humans' efforts and persistence in practices that can lead to achieving the goal. "Buddhism recognises the infinite latent possibilities of man and teaches that man can gain deliverance from suffering by his own efforts independent of divine help or mediating priests» ${ }^{19}$.

According to Mahayana Buddhism, each being possesses the state of Buddha or Buddhahood. At the same time there is no self, soul or any kind of bearer of identity. Therefore each being is both negligible and noble, sacred and profane but in the strict terms of Buddhism, is beyond these opposites.

The division of samsara and nirvana is obvious but at the same time according to the deepest Buddhist teaching they should not be regarded as opposites. Buddhism is a teaching of the Middle Path. This means that in its depths it is a teaching of non-duality that seeks to go beyond all the polarities of the mind including the polarity sacred-profane. This is especially obvious in Mahayana Buddhism which declares a fundamental identity of nirvana (sacred), and samsara (profane). Realisation of this non-duality is interpreted as the essence of Enlightenment or Awakening.

In order to outline more clearly the idea of non-duality, in some Buddhist traditions "even offerings to Buddha often are not with flowers or other good-looking objects, but with garbage and sullage» ${ }^{20}$. There are also the so called Mahasiddhas (great adepts) who «merged the borders between the sacred and the profane by, so to say, the very way of their lives,

[19] Thera, Narada [en línea]: Buddhism in a Nutshell, http://www.buddhanet.net/nutshell03.htm [Consultado: 12/01/2016].

[20] Torchinov, E.: World Religions. p. 19. 
and this was done not by sacralising the profane, as one could assume, but by profanising the sacred, which, of course, was more shocking, and therefore more visible» ${ }^{21}$.

In conclusion, regarding the place of the sacred in Buddhism, it would be correct to say that in terms of Buddhism the real sacredness means to go beyond the opposition sacred-profane, or to achieve no-sacredness. And the profane is to stay on the level of oppositions.

\section{Sacred places in Buddhism}

The importance of practice and coincidence of the different aspects of reality, of the inner and outer dimensions is obvious if we discuss the sacred places in Buddhism.

In strict terms, in the Buddhist reality there should be no sacred places, places which manifest the sacredness from within. However, there might be places sacralised by the presence of an Enlightened being.

At the same time, the enlightened mind sees everything in its primordial truthiness or essence, as it is. All beings unfold the reality in their unique way but the awakened vision perceives Tathata, the suchness of reality, and therefore it sees everything in its new, fresh, wonderful beauty.

While, however, we are in the prison of ignorance and desire, we can perceive only a distorted version of the reality. In such a case, even the highest blissful paradise worlds are equal to the lowest worlds of the hellnothing but a temporal flash of a depended and misguided mind.

If the consciousness is not awakened, it can seek the places where it will be more possible to achieve the ultimate state. These places are points of power and breakthrough into other levels of consciousness. And because the human consciousness is so important, the sacred places of Buddhism are not places of connection and relation with a supernatural being but places of power, points of contact with the true inner suchness, tools to achieve Enlightenment. As the Buddhists put it: «These external objects of reverence are not absolutely necessary, but they are useful as they tend to concentrate one's attention... Instead of petitional prayers there is meditation that leads to self-control, purification and enlighten-

[21] Ibídem, p. 20. 
ment $»^{22}$. So, the sacred places in Buddhism are places that make the practice - the path to enlightenment - easier.

In order to understand the specifics of the sacred places in Buddhism, it would be useful to discuss two of them that are typical for Buddhist religion - stupa and mandala. Representing the two kind of space structuring - vertical and horizontal - they can serve as a good example for understanding the sacred space in Buddhism.

The stupa has a pre-Buddhist origin in burial mounds. Buddhism continues to use it as a container of relics and a monument for special events but gave it such a specific meaning that it was transformed into one of the most representative symbols of Buddhist culture. Stupa is «a visual manifestation of Buddha" and symbol of his Enlightenment and nirvana. In such a way it may be called «an embodiment of sacrality». This sacrality however is unusual. Buddha is not God, neither deity. He is not distant and transcendental. In Theravada Buddhism the image of Buddha is a visual example of the final goal that should motivate the adept. In Mahayana and Vajrayana it is also perceived as the deepest suchness of everybody. Therefore, for the Buddhists the stupa is a manifestation of their own Buddha nature, their own Buddhahood. For this reason, the stupa is not (or should not be) an object of worship but a symbol of the Path that should be travelled. Stupa is not only a symbol. It is also a "concentrated positive energy that can be used ${ }^{23}$. In Buddhist tradition a stupa built according to the rules and initiated by special rituals, is «a generator of spiritual energy. Its aim is to bring harmony and peace to all living beings and to balance natural forces» ${ }^{24}$. In every Buddhist tradition the stupa has a slightly different form and explanation of structure. However, it always remains a powerful symbol of liberation and Enlightenment and is perceived as an energy field that benefits all and brings happiness and peace into the world.

So, the stupa has at least threefold purpose: to show the path and its goal, to help the adept to follow the path and reach the goal, and to benefit all sentient beings.

In order to fulfil this purpose, a stupa should be built, structured and used in accordance with some special conditions.

[22] Thera, Narada: op. cit.

[23] Sokolov, A. [en línea]: Buddhist Stupa. http://stupaman.org/index.shtml [Consultado: 12/01/2016].

[24] Ídem 
It should be built in a special state of mind: concentration of positive impressions, good intentions, gentle wishes, targeted donations, energy and work for the common good.

Buddhists make offerings to the stupas, which means that they honour their goal - Awakening. They consider this ritual to be in tune with their doctrine of pratitya samutpada or mutual arising. According to this doctrine the intent, action and result are in mutual connections and therefore thinking of the goal and making offerings to it helps for identification with that goal and hence - to its achievement.

The principle of mutual connection can be revealed in the very structure and form of the stupa as well. Although different stupas have some differences, there are particular common principles to build it. Analysing the structure of the stupa we can see the interrelations between different aspects of life, and the identity of inner and outer space, of physical and psychical realms.

From one side it is built in the form of Buddha, "crowned and sitting in meditation posture on a lion throne» ${ }^{25}$. In such a way it is an impersonation of the goal - to reach the state of Buddha, and the path to it - peace and meditation. According to the traditional explanation, the stupa represents the Buddha-mind. This mind, however, should be revealed within the adept him/herself.

From the other side, the stupa is made according to the vertical structure of the Universe. In this case it symbolises Mount Sumeru that is considered to be the centre of all the physical, metaphysical and spiritual universes. It is not only the general form of the stupa that represents this universal centre. This Axis Mundi exists inside it as well. It is called «a Tree of Life» and is "wooden pole covered with gems and thousands of mantras, placed in the centre of the Stupa ${ }^{26}$. Through a special ceremony of initiation, it is charged with positive and powerful wishes and ensures the functioning of the stupa.

The cosmic structure can also be revealed in the vertical division of the stupa. In its simplest explanation this vertical structure consists of five parts: foundation, stairs (steps), dome (hemisphere), spire and finial. Each of them has its geometric shape and corresponds to the five elements: earth, water, fire, wind and space.

[25] Allione, Tsultrim: Women in Wisdom. N. Y.: Snow Lion Publication, 2000, p. 59

[26] Strauss, E., 2011. Tibetan Architecture.

http://college.holycross.edu/projects/himalayan_cultures/2011_plans/estrauss/stupas.html. [Consultado: 12/01/2016]. 
The most important, however, is the fact that for the Buddhists the stupa represents in details the path to the goal and is a visual manifestation of their practice.

«Looking at the stupa from the bottom up, we symbolically see all the way to the enlightenment, every level expresses an important step on the way. Buddha, Dharma, Sangha, enlightened spirit and joy as the basis - it is the first step. Then we collect positive experiences, develop a way of uniting the five qualities, and like a vase, become a suitable «receptacle» with sufficient abilities for concentration and meditation. Thirteen rings of the spire this is the final path to the Enlightenment by means of the ten aspects of Buddha's wisdom and knowledge of the three times» ${ }^{27}$. Although different schools explain the meaning of the stupa details slightly differently, they all see it as a symbol of the Enlightened Buddha Mind and of a Perfect Universe.

Therefore the stupa can be viewed as a vertical mandala along with the horizontal mandala, which is another specific symbol of the Buddhist Path in Mahayana and Vajrayana.The word «mandala» means circle, completion and «a container of essence». In Buddhism it again represents the presence of Buddha, the cosmic structure and the path to Enlightenment.The structure of mandala is connected with the doctrine of the three kāyas or bodies of Buddha:

1. The Dharmakāya or a Truth body which embodies the very principle of enlightenment;

2. The Sambhogakāya or a body of bliss;

3. The Nirmānakāya or a physical body which manifests in time and space.

The first two bodies are very close to the concept of God. In Buddhism, however, they should represent both the true nature of reality and the nature of Buddhahood.

The body of bliss has five aspects, representing the five qualities or wisdoms of Buddha. They are "symbolised or embodied» in the Five Dhyani Buddhas. They are connected with the four world directions and the centre.

One of these Buddha aspects is placed in the centre of mandala. It is an embodiment of the essence from which all the structure is emanated and where the path of the adept should end. The building of the mandala begins from this centre, being at first only «a dot... a 'seed', 'sperm', 'drop', the salient starting point. It is the gathering centre where the outside en-

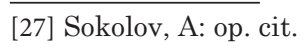


ergies are drawn, and in the act of drawing the forces, the devotee's own energies unfold and are also drawn. Thus it represents the outer and inner spaces. Its purpose is to remove the object-subject dichotomy» ${ }^{28}$.

In the stupa, these five wisdoms are represented in its five vertical levels determining the whole structure of the stupa, while in the mandala only one of them is present but as a focus of the whole structure, the initial point of its unfolding and the ultimate point of its movement. In such a way it presents the pulsation, the transition from One to many, the dynamic of the Universe according to Eastern thought. The centre gradually unfolds into the outer space. At first it forms a circle surrounded by eight Buddhas for meditation - symbolic deities: four male and four female, positioned at the four main and four semi-directions in the form of a lotus flower.

The next level of unfolding is a square - the form of earth and stability. The square is not closed. It has four gates in the four directions of the world. «These four doors symbolise the bringing together of the four boundless thoughts, namely - loving kindness, compassion, sympathy, and equanimity» ${ }^{29}$. The gates are guarded by four doorkeepers. The gates are simultaneously an entry and an exit. They represent the way out from the inner essence to the realisation into the outer space, and the way in - from the outer profane world to the inner depth of sacredness.

In Tibetan stupa their correspondence are the four Buddha eyes in the middle of the structure looking in the four directions.

In order to enter the sacred place, the adept should pass four concentric circles symbolising the obstacles to be overcome and the qualities that should be gained in return. In the stupa this is represented by steps or stairs that should be climbed. In the mandala the circles are:

- a fire of wisdom or purifying fire: its overcoming symbolises «the process of transformation which ordinary human beings have to undergo before entering the sacred territory within $»^{30}$;

- vajra circle (ring of thunderbolt or diamond sceptres (vajra)): the diamond circle that expresses strength and fearlessness and indi cates the «indestructibility and diamond like brilliance of the mandala's spiritual realms $»^{31}$;

[28] Kumar, Natin. [en línea]: Mandala - Sacred Geometry in Buddhist Art | Exotic India, Article of the Month September. 2000. http://www.exoticindiaart.com/article/mandala/ .[Consultado: 12/01/2016].

[29] Ídem

[30] Ídem

[31] Ídem 
- tombs: a circle with eight tombs, which symbolises the «eight aggregates of human consciousness", that the adept must overcome because they "tie man to the phenomenal world and to the cycle of birth and rebirth $»^{32}$;

- a lotus circle: «expresses the open state of devotion, that is necessary in order to enter into» ${ }^{33}$ the innermost place (which in fact is not a place because it is beyond all polarities including the polarities of space and time).

The same alternating of circle and square shapes can be found in the cross-section of the stupa. Both shapes represent the interconnection between earthy and celestial which - according to the Buddhist understanding - are not opposites but complementary aspects of the reality. Awareness of this non-duality is an essential feature of Enlightenment. Stupa represents the path to this Enlightenment as an ascension from the bottom up - a vertical path that has its hidden centre - the united power of the Axis Mundi. Mandala represents it as a penetration into the depth of the cosmos, Buddha mind and one's own being.

The ideal Buddhist temple should unite both structures - the vertical ascension of the stupa and the penetration into the depth of mandala.

\section{Conclusions}

In conclusion, although there are no gods, deities or supernatural powers (all similar figures are ultimately aspects and manifestations of our mind), we can still say that there are sacred places in Buddhism. According to Mircea Eliade, the sacred place is the place revealing "the religious man's will to take his stand at the very heart of the real, at the Centre of the World - that is, exactly where the cosmos came into existence and began to spread out toward the four horizons» ${ }^{34}$. Also, an important characteristic of the sacred place is that it is "open to all directions - in width, upwards and downwards. And the main point is that it is open towards the centre, to the inner dimension, and having a living centre as its uttermost component, this space becomes a space of possibilities $»^{35}$. The sacred

[32] Ídem

[33] Ídem

[34] Eliade, M. 1987. The Sacred and the Profane. New York: A Harvest Book Harcourt, Brace \& World, Inc. , p. 64

[35] Dugin, A. 2009. Postphilosophy. M.: Evraziiskoe dvijenie, p. 86 
objects in Buddhism «map a cosmic center and establish structural orders between a microcosm, its periphery, and an encompassing macrocosm ${ }^{36}$.

In accordance with the principle of non-duality, both paths: from the centre to the periphery and from the periphery to the centre; both structures: stupa and mandala; both models: ascension and penetration, complement each other revealing the identity of micro and macro-cosmos, inner and outer worlds, and sacred spaces within and outside of the precious human being.

\section{Literature:}

Allione, Tsultrim: Women in Wisdom. N. Y.: Snow Lion Publication, 2000

Dugin, A.: Postphilosophy. M.: Evraziiskoe dvijenie, 2009.

Eliade, M.: The Sacred and the Profane. New York: A Harvest Book Harcourt, Brace \& World, Inc., 1987.

ERmakova, T., E. Ostrovskaya: Classical Buddhism, SPb: «Azbuka-classica», «Peterburgskoe Vostokovedenie», 2004.

Kumar, Natin: Mandala - Sacred Geometry in Buddhist Art | Exotic India, Article of the Month September. 2000. http://www.exoticindiaart.com/ article/mandala/

Laynton, R.: Behind the Mask of God. UK: Stoke-on-Trend: Companion Guides, 2013.

Nagarjuna: Ratnavali (Precious Garland), in: Frauwallner, E.: Anthology of Buddhist Philosophy. Sofia: Evrasia. 1995.

Reynolds, F. and Jason A. Carbine eds.: The Life of Buddhism. Berkeley and Los Angeles, California: University of California Press, 2000.

Schober, J.: A Tooth Relic and the Legitimation of Power. In: The Life of Buddhism. Berkeley and Los Angeles, California: University of California Press, 2000.

Sokolov, A. Buddhist Stupa. http://stupaman.org/index.shtml

[36] Schober, J.: A Tooth Relic and the Legitimation of Power. In: The Life of Buddhism. Berkeley and Los Angeles, California: University of California Press. 2000, p. 56. 
STRauss, E., Tibetan Architecture. 2011.

http://college.holycross.edu/projects/himalayan_cultures/2011_plans/estrauss/ stupas.html.

Thera, N. Buddhism in a Nutshell, http://www.buddhanet.net/nutshell03.htm Torchinov, E.: World Religions. SPb: Centre «Peterburgskoe Vostokovedenie», 1998.

Torchinov, E.: Introduction into Buddhism. SPb: The Philosophical Society of Sankt-Petersburg, 2000.

Watts, A.: Buddhism: The Religion of Non-Religion. Boston: Tuttle Publishing, 1999. 